Proc. Indian Acad. Sci., Vol 87 A (E \& P Sciences), No. 3, March 1978, pp. 29-45, (C) printed in India.

\title{
Incursion of the Pacific Ocean Water into the Indian Ocean
}

\author{
G S SHARMA*, A D GOUVEIA and SHUBHA SATYENDRANATH \\ National Institute of Oceanography, Dona Paula 403 004, Goa \\ *Present Address: Department of Marine Sciences, University of Cochin, Foreshore \\ Road, Cochin 682016
}

MS received 25 July 1977; in final form 17 November 1977

\begin{abstract}
Using the data collected during the International Indian Ocean Expedition, maps showing the distribution of depth, acceleration potential, salinity and oxyty were prepared for the northeast monsoon for the four potential thermosteric anomaly surfaces: $160,120,80$ and $60 \mathrm{cl} / \mathrm{t}$. Zonal components of current along $84^{\circ} \mathrm{E}$ were computed from the geopotential dynamic heights. From such an analysis, it became clear that low-salinity water from the Pacific intrudes into the western Indian Ocean through the Banda and Timor seas in the upper layers above $100 \mathrm{cl} / \mathrm{t}$ surface, while the North Indian Ocean Water penetrates towards the Eastern Archipelago below $100 \mathrm{cl} / \mathrm{t}$ surface. The South Equatorial Countercurrent and the Tropical Countercurrent are well depicted on the vertical section of zonal components as well as on the distribution of acceleration potential.
\end{abstract}

Keywords. Ocean expedition; depth distribution; acceleration potential; oxyty.

\section{Introduction}

As early as 1942 Sverdrup et al (1942) remarked that at the Dana Station 3849, located to the southwest of Sumatra, the low-salinity water of temperature higher than $10^{\circ} \mathrm{C}$ is probably of Pacific origin. Wyrtki (1957), for the first time, identified the Pacific Ocean Water in the Indian Ocean. Subsequently, its presence was confirmed by Wyrtki (1961), Taft (1963) and Sharma (1972). Warren et al (1966) considered that the low-salinity water at intermediate depths in the northwestern Indian Ocean could be the Subtropical Subsurface Water, and concluded that the Pacific Ocean would not be the source of the low-salinity water in the western Indian Ocean. Tchernia et al (1958) suggested this water to be the Antarctic Intermediate Water. In view of these differences of opinion, we have made a critical examination of incursion of the Pacific Ocean Water into the Indian Ocean by studying the geostrophic flow and the distribution of water properties on potential thermosteric anomaly surfaces at intermediate depths.

The South Equatorial Countercurrent discovered by Reid (1959) and the Tropical countercurrent (called Subtropical Countercurrent by Yoshida and Kidokoro 1967a, 1967b; Uda and Hasunuma 1969) could be traced on meridional sections by Sharma (1976a). But their presence either on level surfaces or steric surfaces could not be clearly demonstrated in the Indian Ocean, probably because of either paucity of data (Taft 1963; Sharma 1972) or averaging over vast areas just as in the International Indian Ocean Expedition Atlas (Wyrtki 1971). Hence an examination of the presence of these two currents in the geostrophic flow at different potential thermosteric anomaly surfaces has been considered essential. 


\section{Treatment of the material}

This study is based on the data collected during the International Indian Ocean Expedition at 90 stations from various ships. Table 1 lists all the stations, and their geographical positions are shown in figure 1 . All the stations were occupied during the northeast monsoon. The choice of the stations was made on the basis of their geographical distribution and the depth of observation. Preference was given for meridional sections from single cruises and stations which were worked in a single year. Because of abnormality in the weather as well as in oceanographical conditions in 1963 (Uda and Nakamura 1973), the data collected in 1963 were avoided as far as possible.

Potential temperature for each sample of all stations was computed using nomograms prepared by R B Montgomery and M J Pollak from Helland-Hansen's computations (1930). For each station, potential temperature was plotted against depth, salinity and oxyty on a grid with overprinted isopleths of thermosteric anomaly. The values of depth, salinity and oxyty at each chosen potential thermosteric anomaly surface were read directly from the station curves.

Geostrophic flow along the surfaces was deduced from the gradient of acceleration potential (Montgomery 1937; Montgomery and Spilhaus 1941; Montgomery and Stroup 1962) or Montgomery function as it has often been termed (Reid 1965). The expression of acceleration potential used for numerical computation is

$$
\int_{\delta_{\theta_{0}}}^{\delta_{\theta}} P d \delta_{\theta}+P_{0} \delta_{\theta_{0}}
$$

where $\delta_{\theta_{0}}$ is potential thermosteric anomaly at the reference pressure $\left(p_{0}\right)$. The reference pressure for this numerical integration has been chosen to be $2,000 \mathrm{db}$.

The distribution of properties and the geostrophic flow along surfaces of 160,120 , 80 and $60 \mathrm{cl} / \mathrm{t}$ are presented in figures 2 to 9 . In order to have a quantitative estimate of the flow and also the depth to which a particular flow is consistent, zonal components of current at $84^{\circ} \mathrm{E}$ were estimated from geopotential dynamic heights and these have been presented in figure 10. The presentation of the geostrophic flow through the vertical section is adapted from Montgomery and Stroup (1962). The width of

Table 1. List of stations and cruise abbreviations used in figure 1, from International Indian Ocean Expedition.

\begin{tabular}{lcll}
\hline Vessel and expedition & No. of stations used & \multicolumn{1}{c}{ Period } & Abbreviation \\
\hline Argo Lusiad III & 1 & Dec. 11, 1962 & Ar \\
Atlantis Cruise 8 & 2 & Nov. 6-8, 1963 & An \\
Diamantina Cruise 4/62 & 7 & Oct. 24-Nov. 10, 1962 & Dm \\
Discovery IIOE Cruise 3 & 7 & Mar. 20-Apr. 10, 1964 & Di \\
Kagoshima Maru & 12 & Dec. 7, 1963-Jan. 9, 1964 & KB \\
Koyo Maru Cruise 14 & 7 & Nov. 30, 1962-Jan. 1, 1963 & Ko \\
Koyo Maru Cruise 16 & 4 & Jan. 20-25, 1964 & Ko \\
Umitaka Maru & 9 & Jan. 5-22, 1964 & Ut \\
Vityaz Cruise 31 & 19 & Dec. 19, 1959-Mar. 22, 1960 & Vi \\
Vityaz Cruise 33 & 22 & Dec. 11, 1960-Jan 10, 1961 & Vi \\
\hline
\end{tabular}

Stations circled in figure 1 relate to computation of zonal components of the currents. 


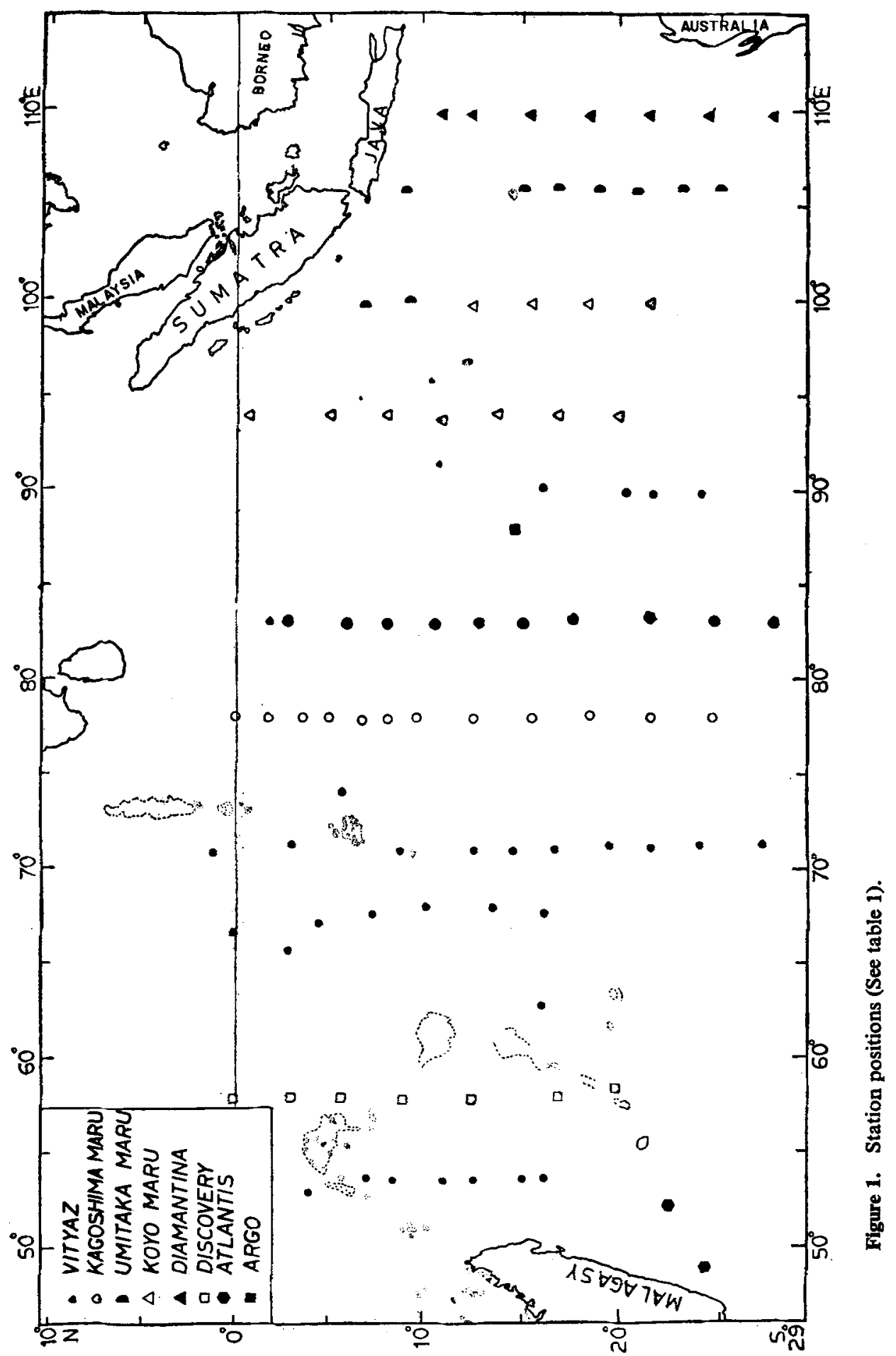


the band represents the magnitude, and the sign is represented by shaded and stippled bands.

\section{Distribution of properties on potential isanosteric surfaces}

\subsection{Depth}

Northward from $20^{\circ} \mathrm{S}, 160 \mathrm{cl} / \mathrm{t}$ surface slopes upward a ridge associated with the northern boundary of the South Equatorial Current. The ridge is shallowest between $60^{\circ} \mathrm{E}$ and $75^{\circ} \mathrm{E}$. In general, this surface slopes up slightly westward (figure $2 \mathrm{a}$ ). The trough noticed on $160 \mathrm{cl} / \mathrm{t}$ surface along $20^{\circ} \mathrm{S}$ is not traced on $120 \mathrm{cl} / \mathrm{t}$, perhaps

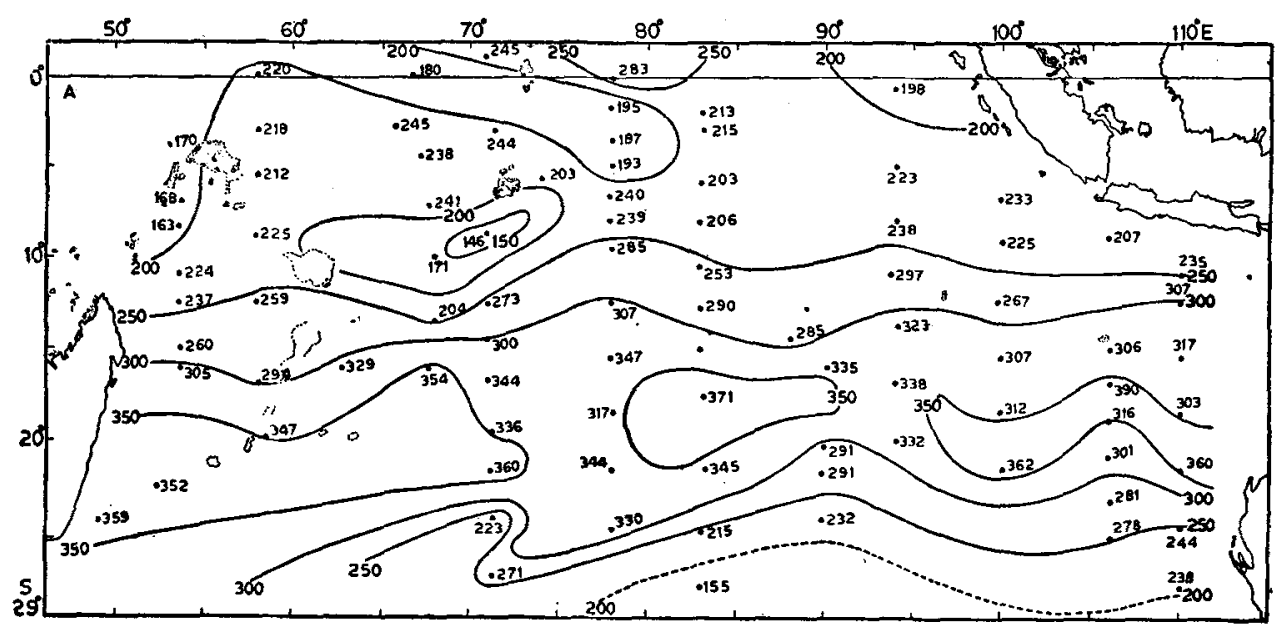

(a)

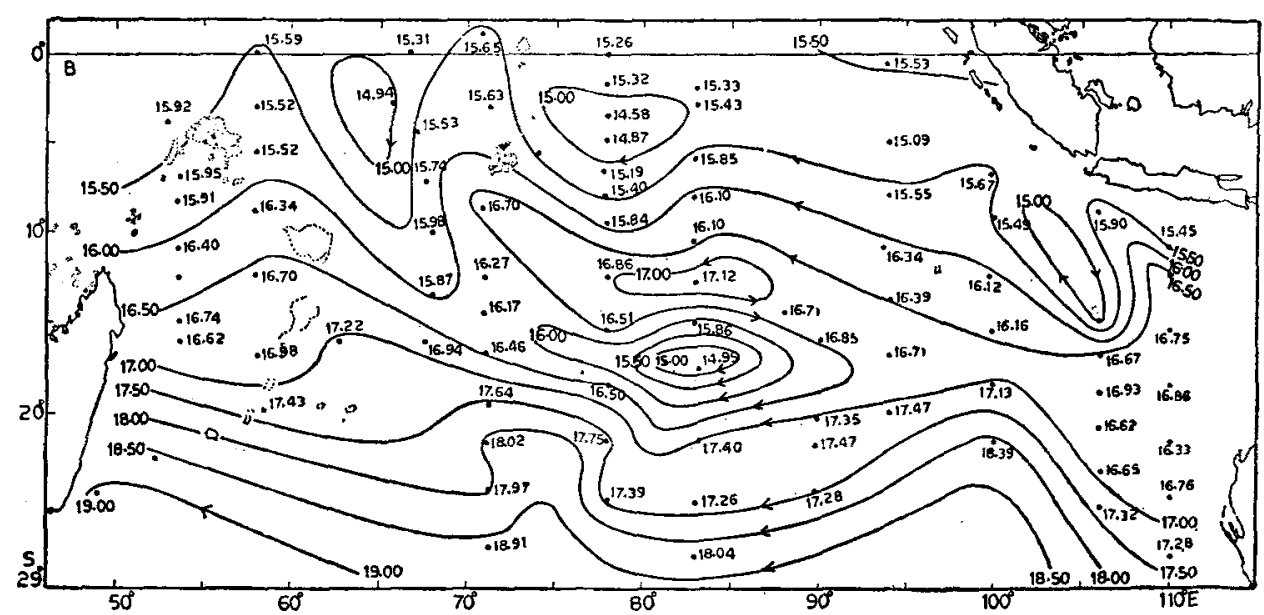

(b)

Figure 2. Depth in metres (a) acceleration potential (joules $/ \mathrm{kg}$ ) relative to $2,000 \mathrm{db}$ (b) at $\delta_{\theta}=160 \mathrm{cl} / \mathrm{t}$. 


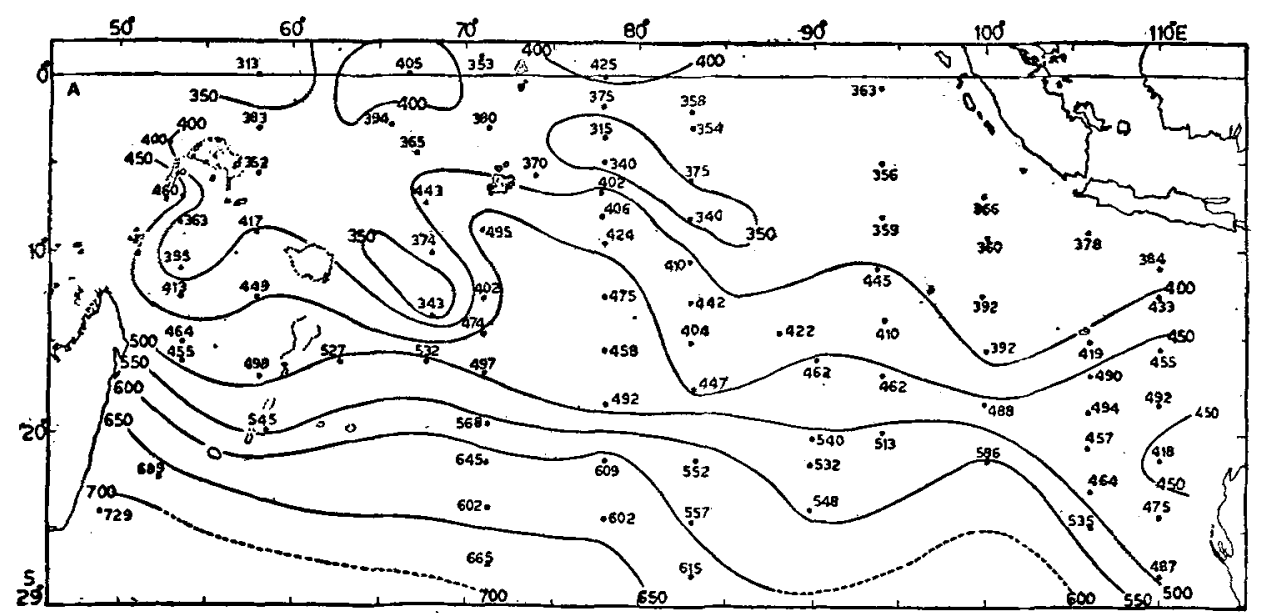

(a)

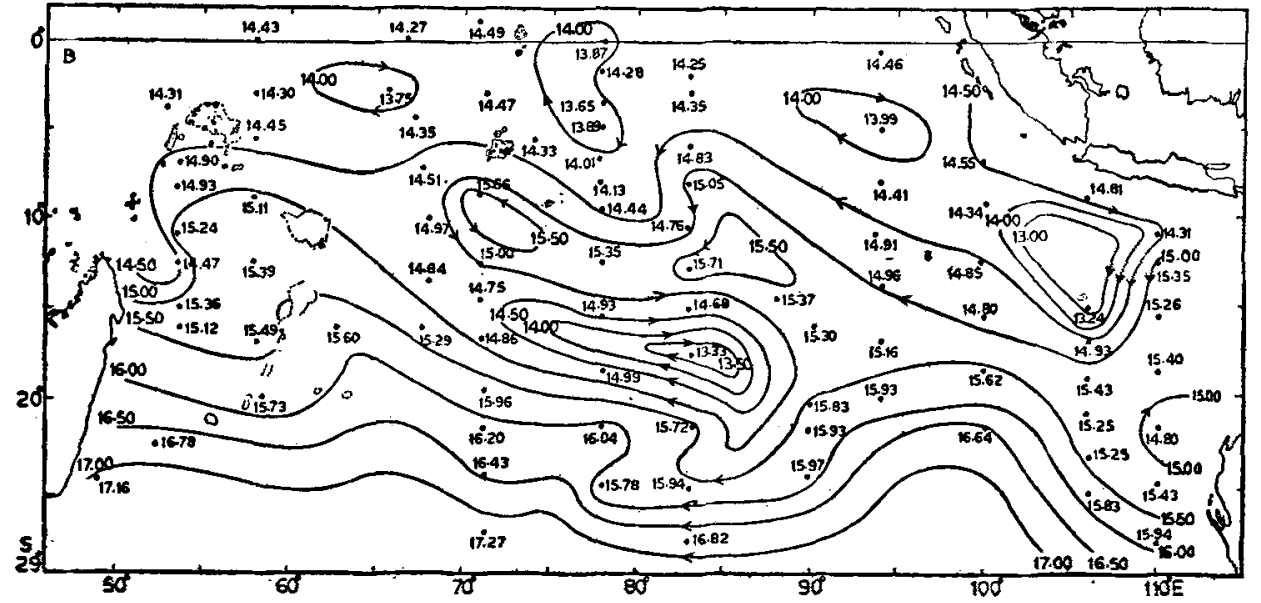

(b)

Figure 3. Depth in metres (a) acceleration potential (joules $/ \mathrm{kg}$ ) relative to $2,000 \mathrm{db}$ (b) at $\delta_{\theta}=120 \mathrm{cl} / \mathrm{t}$.

because of its southward shift. A trough with depths ranging from 500 to $700 \mathrm{~m}$, is located between $20^{\circ} \mathrm{S}$ and $35^{\circ} \mathrm{S}$ on $125 \mathrm{cl} / \mathrm{t}$ potential isosteric surface (Taft 1963, figure 4). The ridge, present slightly north of $10^{\circ} \mathrm{S}$ on $160 \mathrm{cl} / \mathrm{t}$ surface, is also noticed on $120 \mathrm{cl} / \mathrm{t}$ surface, slightly northward but in a distorted manner.

The lower surfaces $(80$ and $60 \mathrm{cl} / \mathrm{t}$ ) slope meridionally more steeply than the upper surfaces (160 and $120 \mathrm{cl} / \mathrm{t}$ ). The distribution pattern of depth on the surfaces of 80 and $60 \mathrm{cl} / \mathrm{t}$ varies markedly from that of 160 and $120 \mathrm{cl} / \mathrm{t}$ surfaces. On the former surfaces, between $10^{\circ} \mathrm{S}$ and $20^{\circ} \mathrm{S}$, there are alternate troughs and ridges of small scale. Conspicuously, the orientation of depth contours of the surfaces 80 and 60 $\mathrm{cl} / \mathrm{t}$ are similar. In the easternmost area of the study, the steep ridges on these surfaces, probably indicate the reversal of the flow in this region from that of the upper steric surfaces. The ridges along $15^{\circ} \mathrm{S}$ and the troughs at about $10^{\circ} \mathrm{S}$, approximately, mark the southern and northern boundaries of the South Equatorial Countercurrent. 


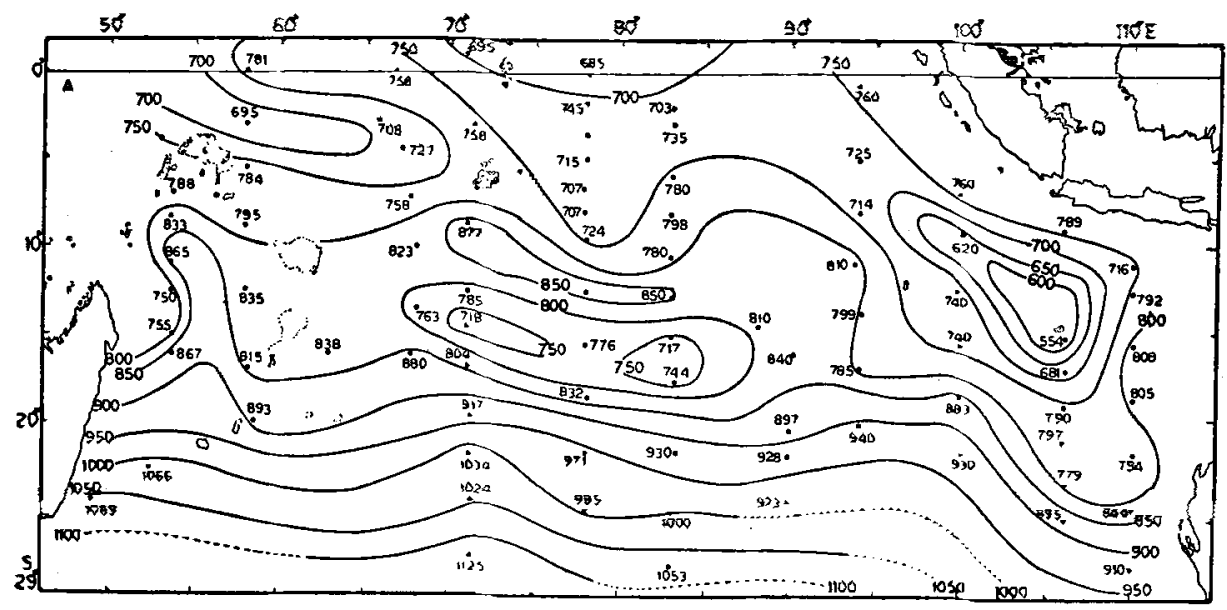

(a)

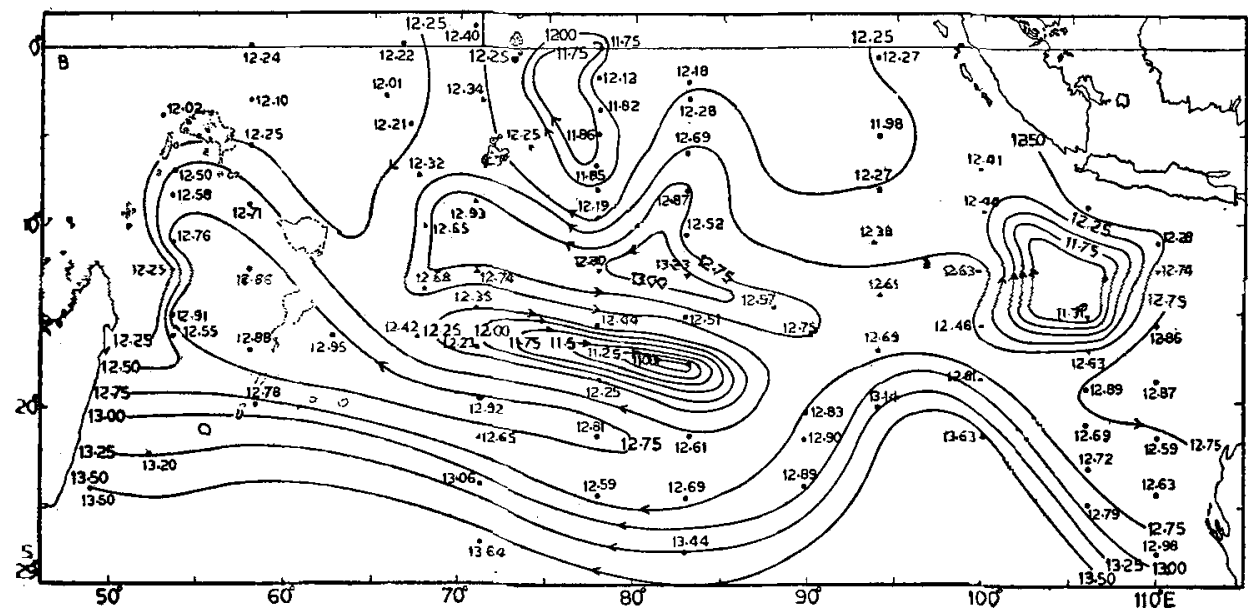

(b)

Figure 4. Depth in metres (a) acceleration potential (joules $/ \mathrm{k}_{\mathrm{B}}$ ) relative to $2,000 \mathrm{db}$ (b) at $\delta_{\theta}=80 \mathrm{cl} / \mathrm{t}$.

\subsection{Acceleration potential}

The distribution of acceleration potential (figures $2 b, 3 b, 4 b, 5 b$ ) relative to $2,000 \mathrm{db}$ clearly reveals the South Equatorial Countercurrent between $12^{\circ} \mathrm{S}$ and $15^{\circ} \mathrm{S}$ in the central region on all surfaces. There is a slight southward shift of the core of this current with lower steric levels. The northern and southern boundaries of th is current are indicated by the maximum and minimum values of acceleration potential. The eastward flowing Tropical Countercurrent, located between $22^{\circ} \mathrm{S}$ and $26^{\circ} \mathrm{S}$ (Sharma 1976a), is evident on 80 and $60 \mathrm{cl} / \mathrm{t}$ surfaces by the lower values of acceleration potential south of $20^{\circ} \mathrm{S}$. The isopleths of acceleration potential, if drawn at a closer interval would have certainly given a clearer evidence of the Tropical Countercurrent. Its presence is more prominent and spreads over the whole width of the ocean at iower steric levels. Nevertheless, relatively lower values of acceleration potential between 


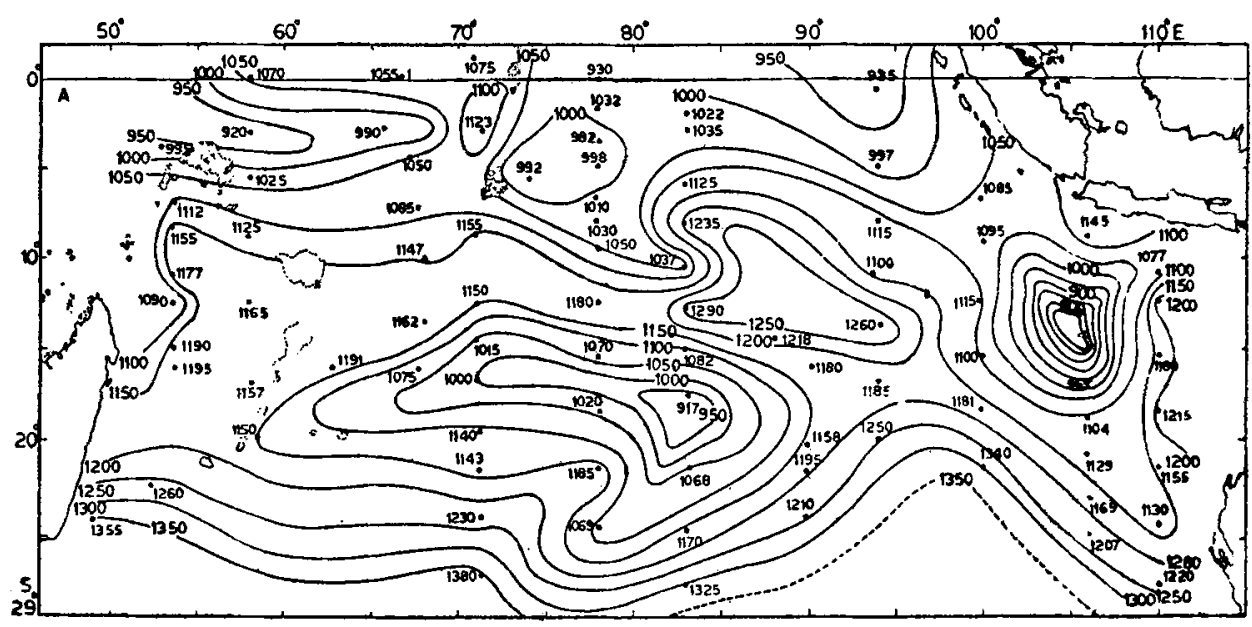

(a)

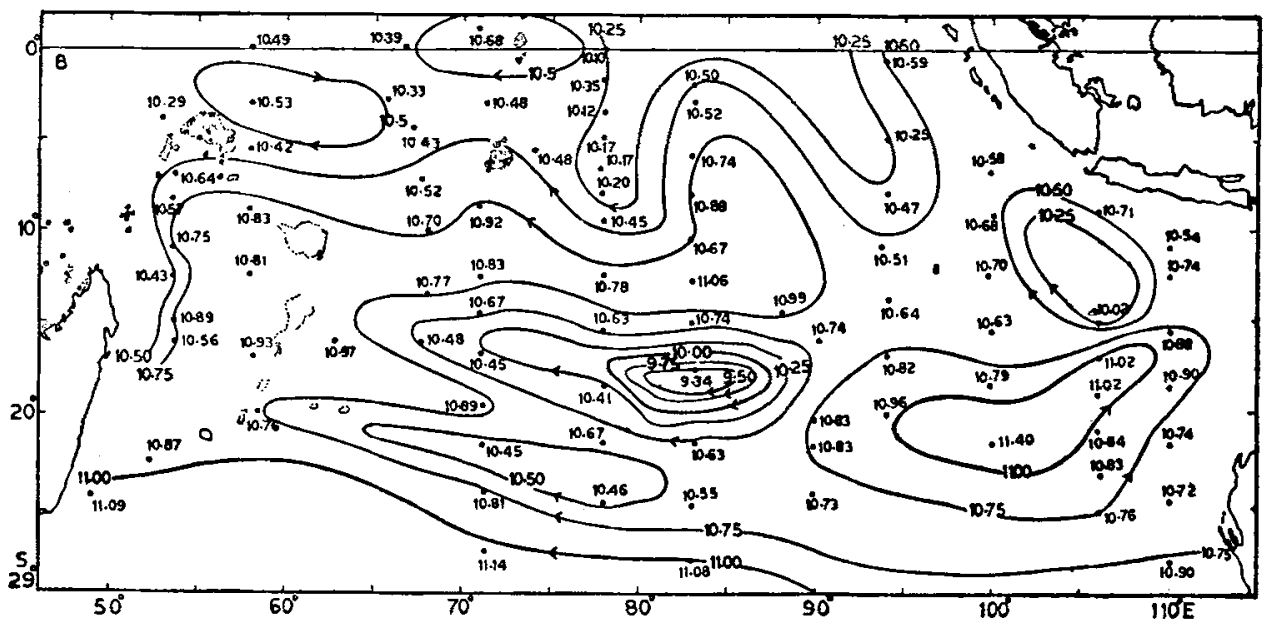

(b)

Figure 5. Depth in metres (a) acceleration potential (joules $/ \mathrm{kg}$ ) relative to $2,000 \mathrm{db}$ (b) at $\delta_{\theta}=60 \mathrm{cl} / \mathrm{t}$.

$21^{\circ} \mathrm{S}$ and $25^{\circ} \mathrm{S}$ on 160 and $120 \mathrm{cl} / \mathrm{t}$ surfaces are consistent with the presence of the Tropical Countercurrent located at these latitudes.

On $160 \mathrm{cl} / \mathrm{t}$ surface, there is an inconsistency between the distribution of acceleration potential and depth in the southernmost area under study. While this surface slopes up southward, the acceleration potential is seen to be increasing (figure $2 \mathrm{~b}$ ) in contrast to the general increase of acceleration potential at any surface with the increase of its depth. The reason for such a deviation on this surface alone is not immediately known. Probably, this surface may be in the layer of transition between two layers of opposing flows. The geopotential topography charts at $100 \mathrm{db}$ and $300 \mathrm{db}$ surfaces relative to $1,000 \mathrm{db}$ during November and December reveal the opposing flows between $20^{\circ} \mathrm{S}$ and $25^{\circ} \mathrm{S}$ (Wyrtki 1971, pp. 375-381).

The geostrophic flow on 160 and $120 \mathrm{cl} / \mathrm{t}$ surfaces is mostly zonal, whereas in the 
central equatorial region there is an indication of transequatorial flow on 80 and $60 \mathrm{cl} / \mathrm{t}$ surfaces. Just as the distribution of depth the acceleration potential distribution in the easternmost region under study reveals a marked variation in the flow pattern between the upper $(160 \mathrm{cl} / \mathrm{t}, 120 \mathrm{cl} / \mathrm{t})$ and the lower $(80 \mathrm{cl} / \mathrm{t}, 60 \mathrm{cl} / \mathrm{t})$ surfaces (figures $2 \mathrm{~b}, 3 \mathrm{~b}, 4 \mathrm{~b}, 5 \mathrm{~b})$. Down the stream, west of $70^{\circ} \mathrm{E}$, the South Equatorial Current branches northward to join the Equatorial Countercurrent, and southward to flow along the coast of Malagasy (figures $3 \mathrm{~b}, 4 \mathrm{~b}, 5 \mathrm{~b}$ ).

\subsection{Salinity}

The most striking feature in the distribution of salinity is, consistent with the distribution of depth and acceleration potential, similarity between 160 and $120 \mathrm{cl} / \mathrm{t}$ surfaces, and between 80 and $60 \mathrm{cl} / \mathrm{t}$ surfaces.

In the South Indian Ocean, the dominant water type in the thermocline is the Tropical Water which is formed in the surface salinity maximum (above $160 \mathrm{cl} / \mathrm{t}$ ). Below this surface, its predominance is decreased with depth. At $120 \mathrm{cl} / \mathrm{t}$ the salinity maximum of the tropical origin, noticed on $160 \mathrm{cl} / \mathrm{t}$ is weakened and also shifted northward. There is no salinity maximum either at 80 or $60 \mathrm{cl} / \mathrm{t}$ at these latitudes $\left(15^{\circ} \mathrm{S}-25^{\circ} \mathrm{S}\right)$.

The low-salinity tongues, extending along $11^{\circ} \mathrm{S}$ from $110^{\circ} \mathrm{E}$ as far west as $53^{\circ} \mathrm{E}$ and $70^{\circ} \mathrm{E}$ on $160 \mathrm{cl} / \mathrm{t}$ and $120 \mathrm{cl} / \mathrm{t}$ surfaces respectively, are of particular interest. Around this latitude the vertical distribution of salinity from station curves (not included in this paper) shows a salinity minimum below the surface of $200 \mathrm{cl} / \mathrm{t}$ with values ranging from $34.6 \%$ at $110^{\circ} \mathrm{E}$ to less than $35.1 \%$ at $53^{\circ} \mathrm{E}$. In order to indicate the westward extent of low-salinity water on $160 \mathrm{cl} / \mathrm{t}$ surface, the isohaline of $35.1 \%$ is drawn with dashes. The salinity in the low-salinity tongue increases westward from values less than $34.6 \%$ at $110^{\circ} \mathrm{E}$ to values less than $35.1 \%$ near the coast of Malagasy (figure 6a). This increase in salinity suggests that the low-salinity tongue is maintained by a west-ward transport of low-salinity water in the South Equatorial current, because the low-salinity water in the tongue is distinctly separated from the high-salinity waters of the north and south of the tongue. Furthermore, the salinity minimum in the western equatorial Pacific is conspicuous at about $160 \mathrm{cl} / \mathrm{t}$ (Tsuchiya 1968, figure 1a), with salinity less than $34.6 \%$, and the low-salinity tongue must be the consequence of the Pacific Ocean water. The water in this tongue is characterized vertically by a salinity minimum. The vertical salinity minimum may be seen most clearly on the vertical sections along the various longitudes, in the International Indian Ocean Expedition Atlas (Wyrtki 1971, pp. 412, 440, 464, 497, 506, 510, 512). The low-salinity tongue, therefore, is not a result of vertical mixing but indicates that the low-salinity water from the Pacific is flowing westward with the South Equatorial Current. As the low-salinity water flows westward, replenishment of salinity by lateral mixing with the high-salinity water from the west takes place increasing the salinity to values exceeding $35.2 \%$, in the west.

The sharp meridional gradient, south of the low-salinity tongue, is developed because the low-salinity water from the east is carried by the South Equatorial Current while the high-salinity water from the west is carried by the South Equatorial Countercurrent. The latitudinal belt, within which sharp meridional gradient is developed, coincides with the northern boundary of the South Equatorial Countercurrent (figures 6a, 7a), 


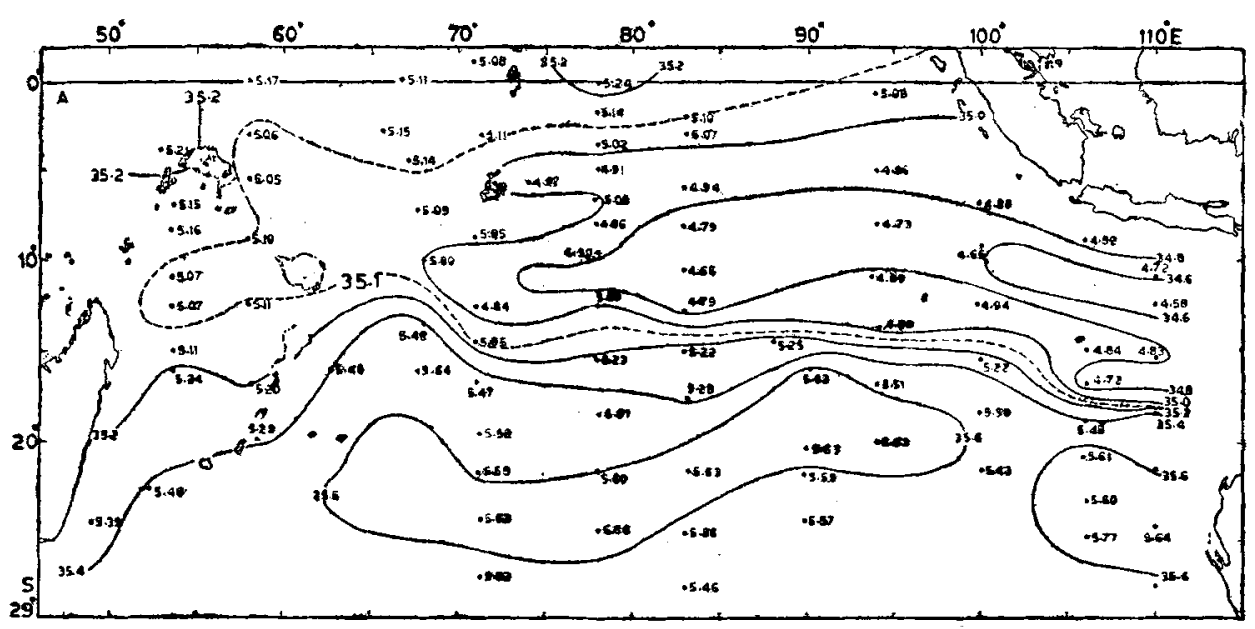

(a)

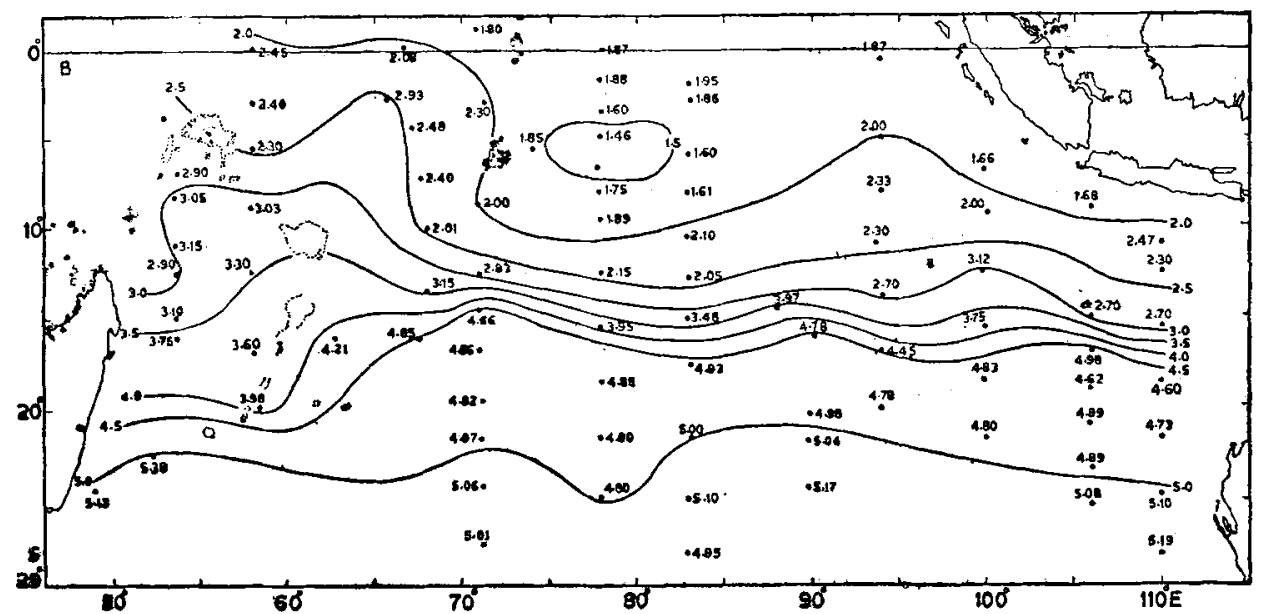

(b)

Figure 6. Salinity in per mille (a) oxyty in $\mathrm{ml} / \mathrm{l}$ (b) at $\delta_{\theta}=160 \mathrm{cl} / \mathrm{t}$.

The southward intrusion of low-salinity water marked by the $34.9 \%$ isohaline near the coast of Malagasy on $120 \mathrm{cl} / \mathrm{t}$ surface suggests the southward branching of the South Equatorial Current flowing along the Malagasy coast.

Marked changes are noticed in the salinity distribution on 80 and $60 \mathrm{cl} / \mathrm{t}$ surfaces from that of 160 and $120 \mathrm{cl} / \mathrm{t}$ surfaces. The low-salinity tongue disappears on the surfaces of $80 \mathrm{cl} / \mathrm{t}$ and $60 \mathrm{cl} / \mathrm{t}$. In contrast, high-salinity water from the northern hemisphere intrudes into the eastern Archipelago indicating the high-salinity water of the northern hemisphere, probably, enters the Pacific through the Banda and Timor seas at deeper depths to compensate the flow into the Indian Ocean. Consistent with this conclusion, relatively high-salinity water is noticed in the western equatorial Pacific on $80 \mathrm{cl} / \mathrm{t}$ surface (Reid 1965). 


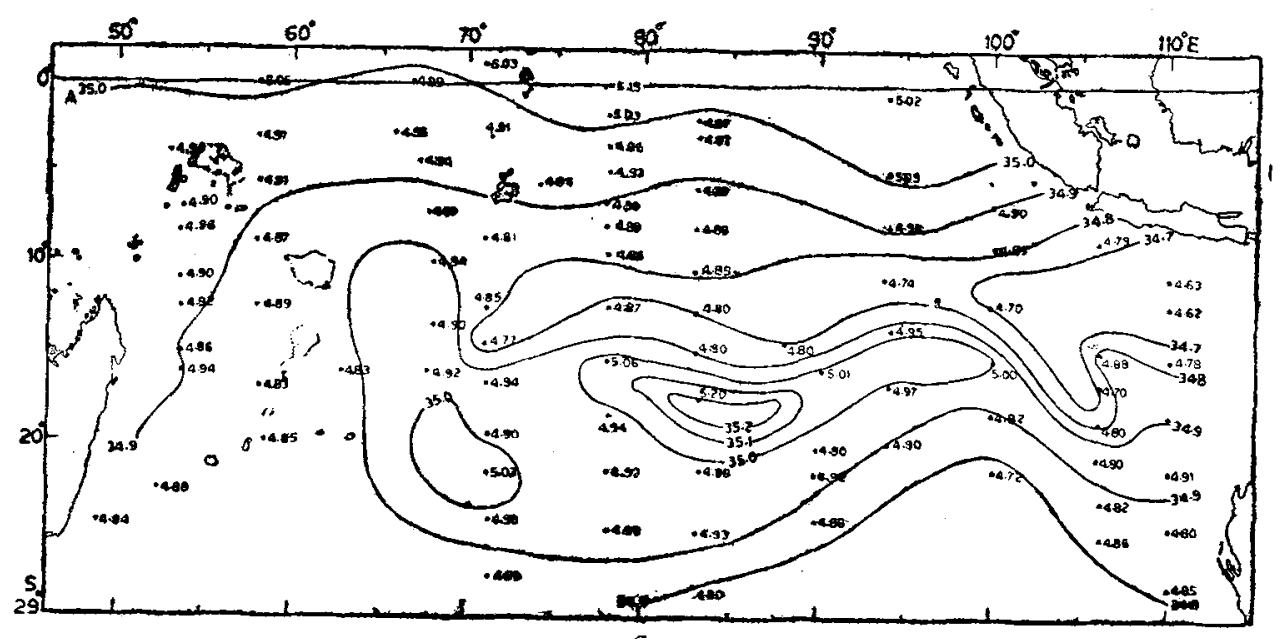

(a)

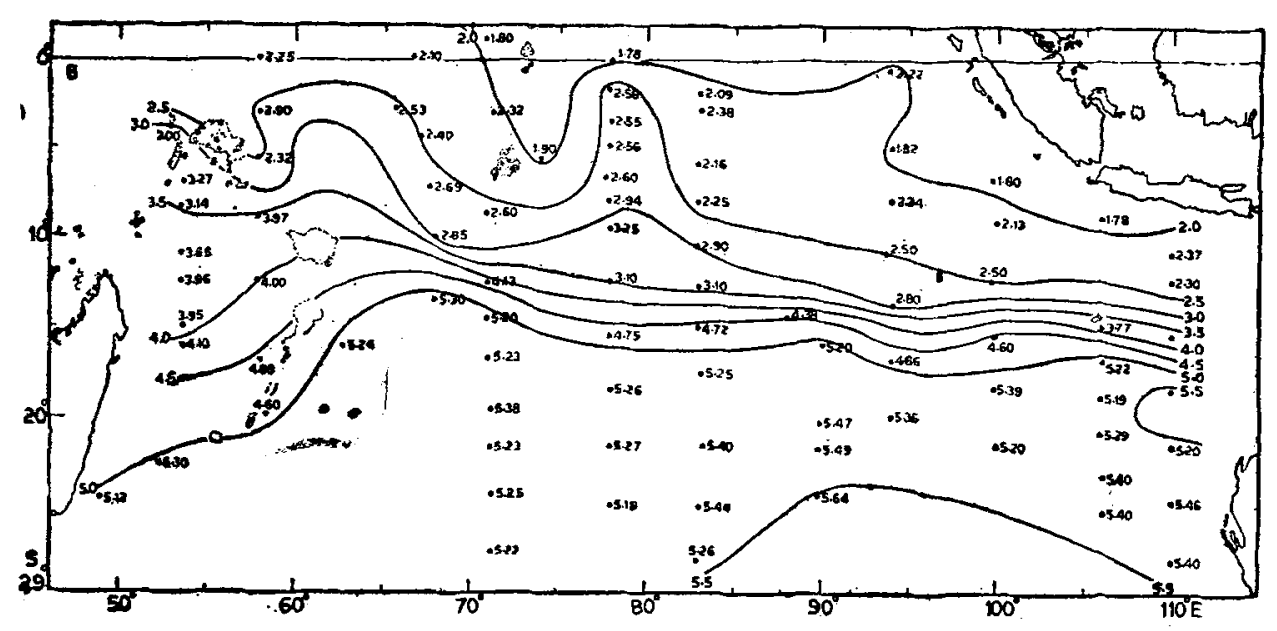

(b)

Figure 7. Salinity in per mille (a) oxyty in $\mathrm{ml} / 1$ (b) at $\delta_{\theta}=120 \mathrm{cl} / \mathrm{t}$.

\subsection{Oxyty}

Similar to the distribution of other properties, the distribution of oxyty on 80 and $60 \mathrm{cl} / \mathrm{t}$ is almost similar while that on 160 and $120 \mathrm{cl} / \mathrm{t}$ surfaces is similar. The major features of oxyty distribution as well as the distribution of other properties on $160 \mathrm{cl} / \mathrm{t}$ surface resemble those on $200 \mathrm{cl} / \mathrm{t}$ surface (Sharma 1972). The oxyty decreases continuously northward on all the surfaces. A sharp meridional gradient is developed on the surfaces of $160 \mathrm{cl} / \mathrm{t}$ and $200 \mathrm{cl} / \mathrm{t}$ in the east. In contrast to the upper two surfaces, the meridional gradient on 80 and $60 \mathrm{cl} / \mathrm{t}$ surfaces, particularly in the east, is very weak. The meridional gradients in oxyty and salinity distributions coinicde with the trough depicted by the depth contours on the surface of $160 \mathrm{cl} / \mathrm{t}$ where the South Equatorial Countercurrent in the central region is displayed on the acceleration 


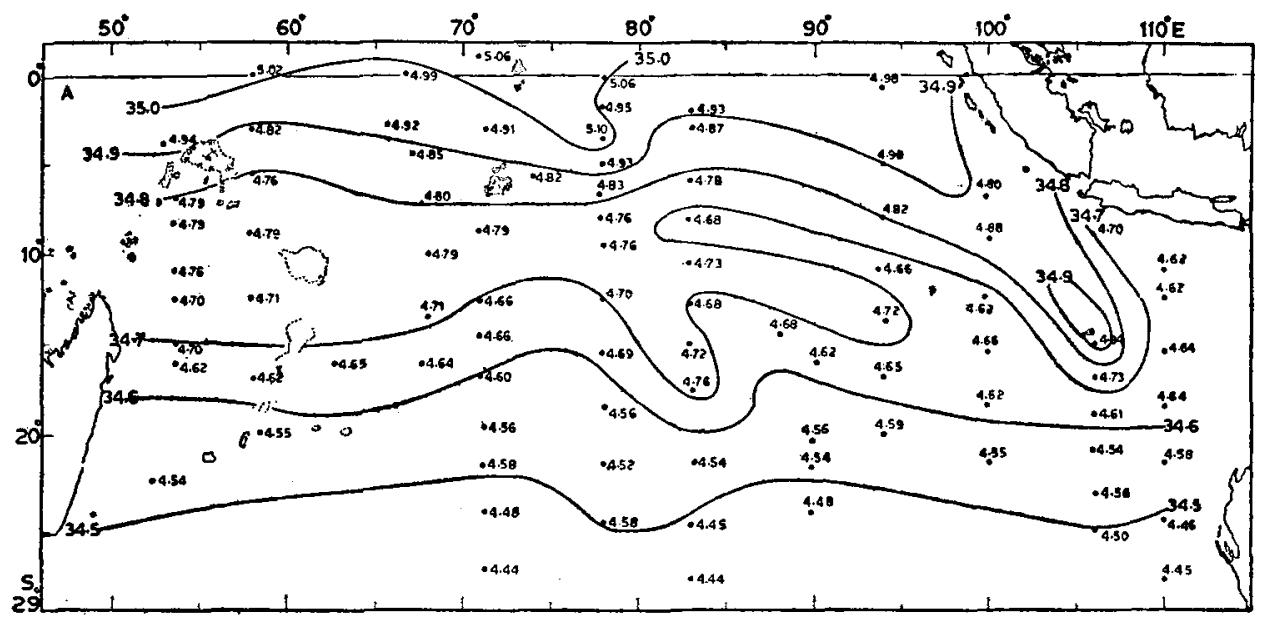

(a)

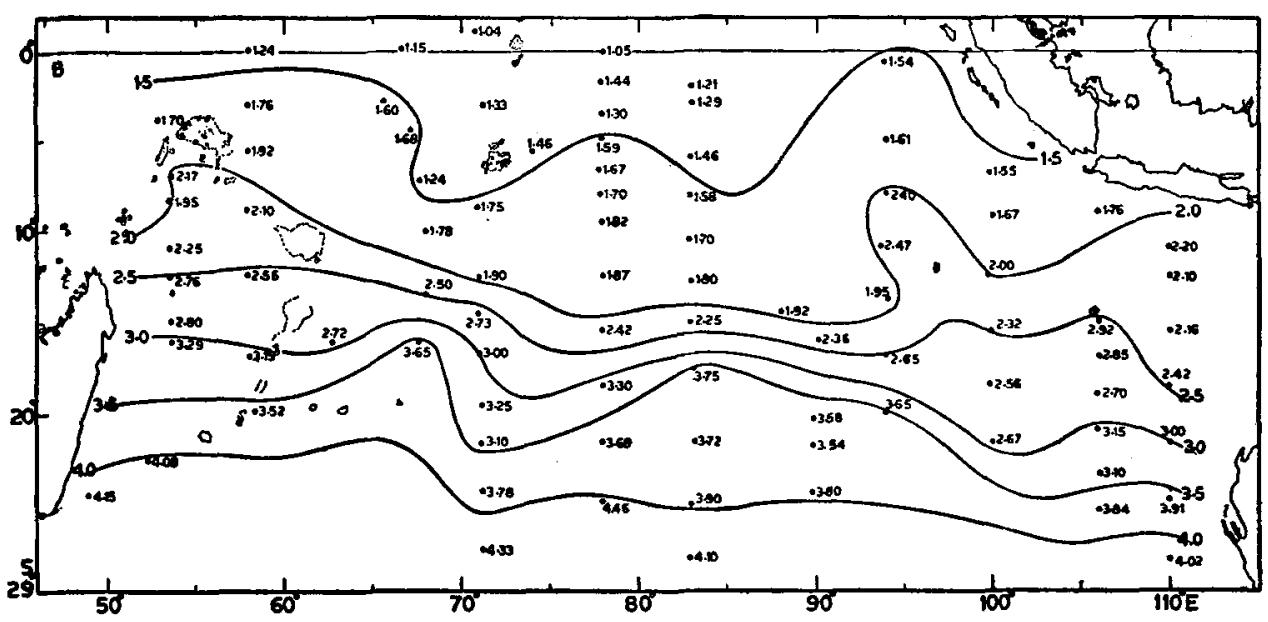

(b)

Figure 8. Salinity in per mille (a) oxyty in $\mathrm{ml} / 1$ (b) at $\delta_{\theta}=80 \mathrm{cl} / \mathrm{t}$.

potential chart. As the water from the east flows, due to lateral mixing with high-oxyty water of the south, there is an increase in oxyty in the west.

Far down stream of the South Equatorial Current, the oxyty values west of $70^{\circ} \mathrm{E}$ are higher in the north and lower in the south than at those latitudes in the east as indicated by the diverging oxypleths on 160 and $120 \mathrm{cl} / \mathrm{t}$ surfaces. Note that the area of spreading to the north is more than that to the south. This distribution suggests that the South Equatorial Current on these surfaces discharges more water to the north than to the south (figures $6 b, 7 b$ ).

\section{Zonal fiow along $84^{\circ} \mathrm{E}$}

Eastward components, representing the Equatorial Countercurrent are found at the northern periphery of the section (figure 10). The magnitude of this current is 


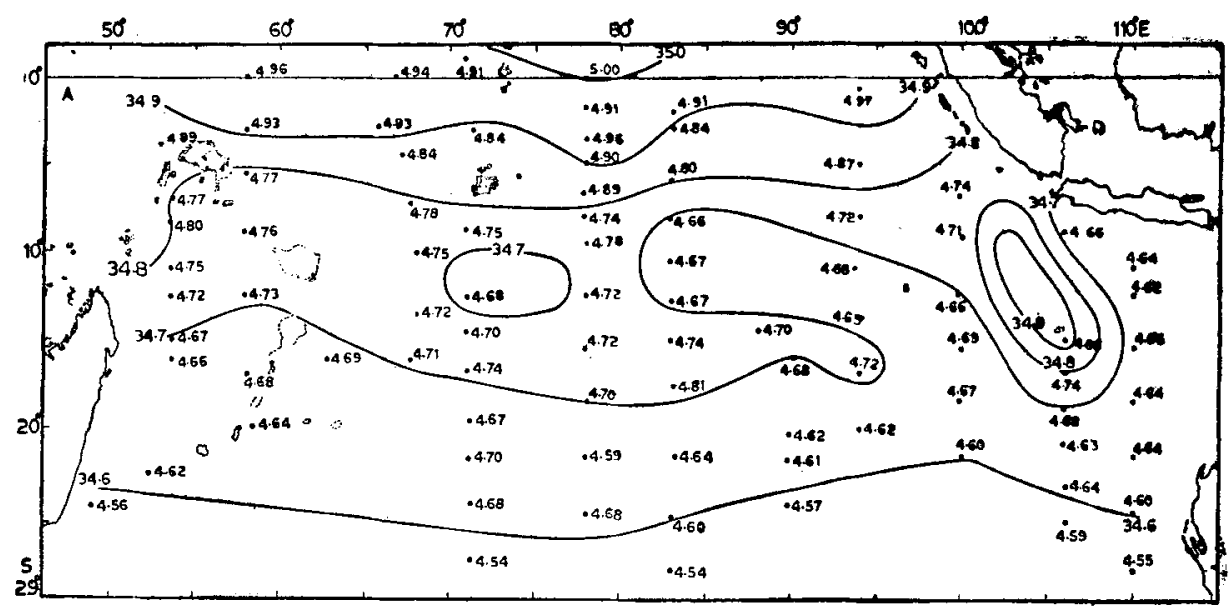

(a)

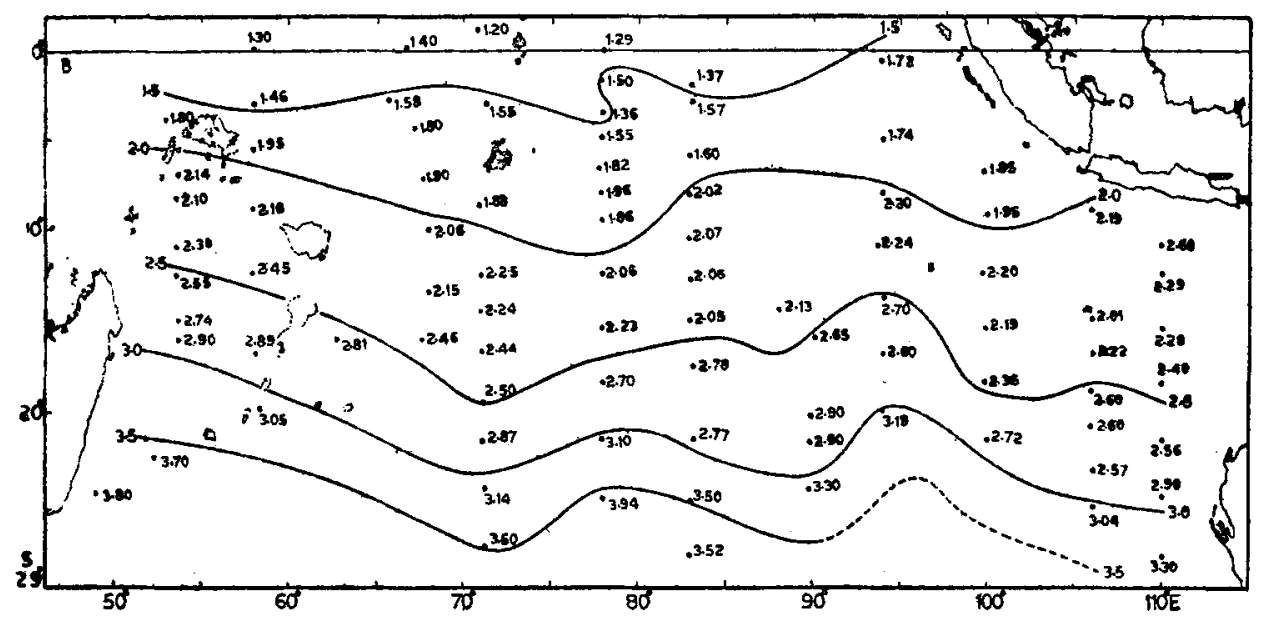

(b)

Figure 9. Salinity in per mille (a) oxyty in $\mathrm{ml} / \mathrm{l}\left(\mathrm{b}\right.$ ) at $\delta_{\theta}=60 \mathrm{cl} / \mathrm{t}$.

$50 \mathrm{~cm} / \mathrm{sec}$ in the surface layers. On this section, only a small cross section of the Equatorial Countercurrent to a depth of about $150 \mathrm{~m}$, bounded by the South Equatorial Current at about $6^{\circ} \mathrm{S}$ is noticed. Between $8^{\circ} \mathrm{S}$ and $10^{\circ} \mathrm{S}$, underneath the westward flowing South Equatorial Current, an easterly current lies. The ridge on the depth distribution at 160 and $120 \mathrm{cl} / \mathrm{t}$ surfaces is associated with the boundary of the easterly flow. The mean zonal component of the South Equatorial Current on this section is about $30 \mathrm{~cm} / \mathrm{sec}$ and it agrees well with that of the zonal component at $65^{\circ} \mathrm{E}$ (Sharma 1976a).

The South Equatorial Countercurrent between $13^{\circ} \mathrm{S}$ and $15^{\circ} \mathrm{S}$ is conspicuous as a narrow band of an easterly flow within the broad South Equatorial Current system. The strength of this current on this section appears to be somewhat fortuitous, indicating a relatively high value in the surface, and it is probably because of an 


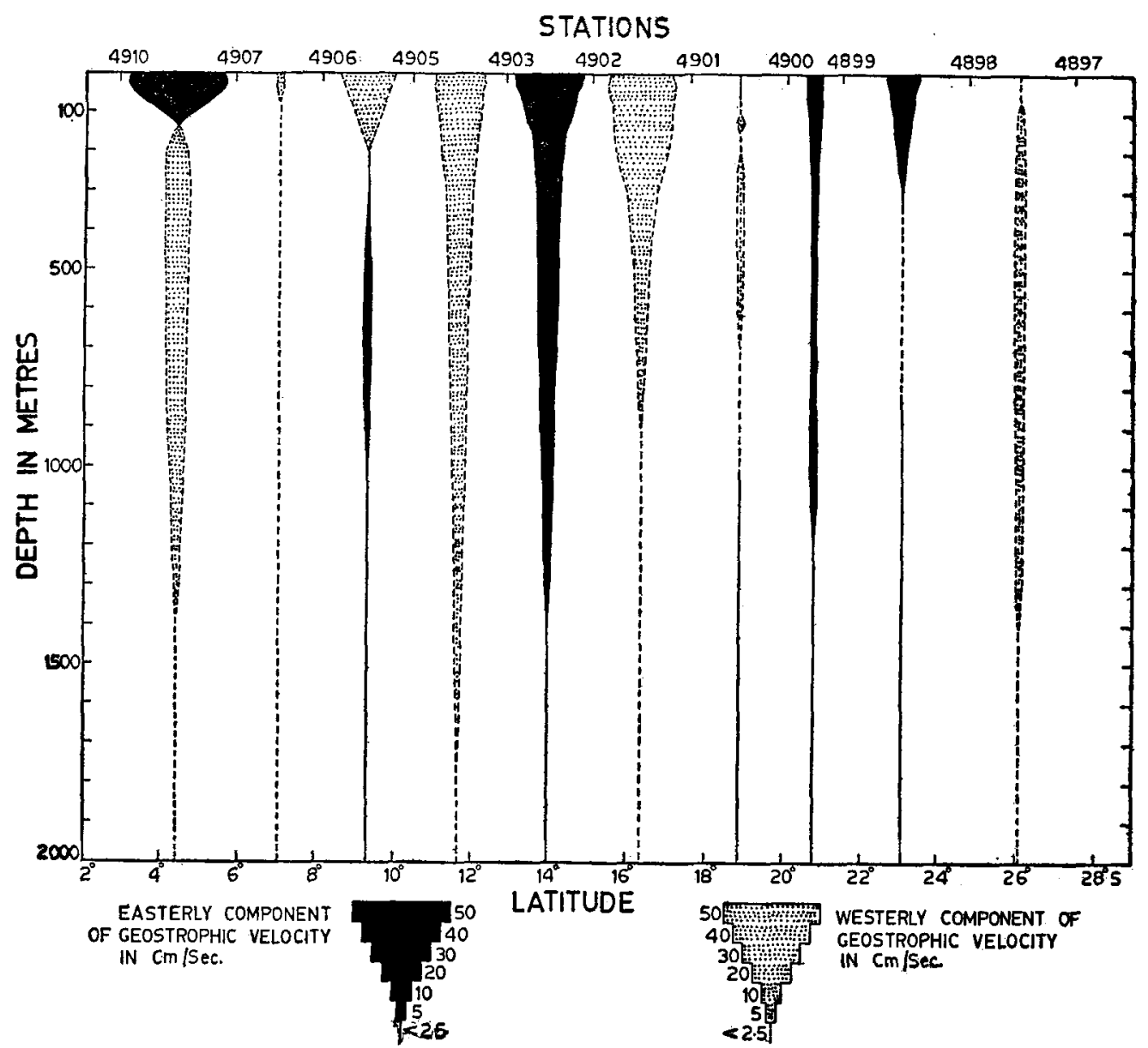

Figure 10. Zonal components of the geostrophic velocity at $84^{\circ} \mathrm{C}$ in $\mathrm{cms} / \mathrm{sec}$.

abnormally low value of dynamic height at Vityaz station 4902. Table 2 represents the zonal components of this current along two neighbouring meridional stations on either side at $78^{\circ} \mathrm{E}$ and $94^{\circ} \mathrm{E}$. On Sharma's map at $65^{\circ} \mathrm{E}$ its strength at the surface is about $20 \mathrm{~cm} / \mathrm{sec}$ and located at about $13^{\circ} \mathrm{S}$ (Sharma 1976a) whereas at $51^{\circ} \mathrm{E}$ it is located at about $10^{\circ} \mathrm{S}$ and its magnitude at the surface is $50 \mathrm{~cm} / \mathrm{sec}$ (Premchand and Sastry 1976). The magnitude of this current at subsurface depths below $100 \mathrm{~m}$ at all the sections is almost of similar magnitude. The latitudinal position of the South Equatorial Countercurrent varies with longitude and shifts towards south as it flows eastward.

The Tropical Countercurrent which is again an easterly current is located between $20^{\circ} \mathrm{S}$ and $24^{\circ} \mathrm{S}$. The width and magnitude of this current on the section at $84^{\circ} \mathrm{S}$ is almost similar to that at $65^{\circ} \mathrm{E}$ and it is slightly shifted northward at $84^{\circ} \mathrm{E}$ relative to that at $65^{\circ} \mathrm{E}$ (Sharma 1976a). A north-south inclination of this current with the latitudinal belt is evident from the acceleration potential charts at surfaces of $80 \mathrm{cl} / \mathrm{t}$ and $60 \mathrm{cl} / \mathrm{t}$. 
Table 2. Zonal components of the geostrophic currents (cm/sec.) relative to $2,000 \mathrm{db}$, along $78^{\circ} \mathrm{E}$ and $94^{\circ} \mathrm{E}$ (Positive-Eastward, Negative-Westward)

\begin{tabular}{|c|c|c|c|c|}
\hline Depth in $m$ & $12^{\circ} 30^{\prime} \mathrm{S}-14^{\circ} 03^{\prime} \mathrm{S}$ & $\begin{array}{l}78^{\circ} \mathrm{E} \\
14^{\circ} 03^{\prime} \mathrm{S}-15^{\circ} 27^{\prime} \mathrm{S}\end{array}$ & ${ }_{12^{\circ} 29^{\prime} \mathrm{S}-13^{\circ} 51^{\prime} \mathrm{S}}^{\text {Al }}$ & $\begin{array}{l}94^{\circ} \mathrm{E} \\
13^{\circ} 51^{\prime} \mathrm{S}-15^{\circ} 27^{\prime} \mathrm{S}\end{array}$ \\
\hline $\begin{array}{r}0 \\
10 \\
20 \\
30\end{array}$ & $\begin{array}{l}21 \cdot 6 \\
21.4 \\
21 \cdot 1 \\
20.9\end{array}$ & $\begin{array}{l}5 \cdot 3 \\
5 \cdot 1 \\
4 \cdot 8 \\
4 \cdot 3\end{array}$ & $\begin{array}{l}14 \cdot 6 \\
15 \cdot 0 \\
15 \cdot 4 \\
16 \cdot 0\end{array}$ & $\begin{array}{l}21 \cdot 3 \\
20 \cdot 6 \\
19 \cdot 7 \\
18 \cdot 8\end{array}$ \\
\hline $\begin{array}{r}50 \\
75 \\
100 \\
125\end{array}$ & $\begin{array}{l}20.9 \\
20.6 \\
17.7 \\
13.1\end{array}$ & $\begin{array}{r}2.2 \\
-\quad 2.9 \\
-7.1 \\
-8.5\end{array}$ & $\begin{array}{l}16 \cdot 3 \\
16 \cdot 3 \\
17 \cdot 1 \\
17 \cdot 1\end{array}$ & $\begin{array}{l}17 \cdot 6 \\
16 \cdot 7 \\
14.9 \\
11 \cdot 7\end{array}$ \\
\hline $\begin{array}{l}150 \\
200 \\
250 \\
300\end{array}$ & $\begin{array}{r}10.2 \\
8.8 \\
7.8 \\
6.8\end{array}$ & $\begin{array}{r}-8.5 \\
-10.2 \\
-\quad 3.2 \\
0.0\end{array}$ & $\begin{array}{l}16 \cdot 7 \\
14 \cdot 4 \\
13 \cdot 1 \\
12 \cdot 9\end{array}$ & $\begin{array}{l}8.4 \\
5.3 \\
3.9 \\
2.7\end{array}$ \\
\hline $\begin{array}{l}400 \\
500 \\
600 \\
700\end{array}$ & $\begin{array}{l}4 \cdot 8 \\
3 \cdot 2 \\
2 \cdot 4 \\
1 \cdot 7\end{array}$ & $\begin{array}{l}3 \cdot 9 \\
5 \cdot 6 \\
6.6 \\
7 \cdot 7\end{array}$ & $\begin{array}{r}11 \cdot 2 \\
9.9 \\
10 \cdot 5 \\
10 \cdot 3\end{array}$ & $\begin{array}{l}1 \cdot 4 \\
1 \cdot 7 \\
1 \cdot 7 \\
1 \cdot 4\end{array}$ \\
\hline $\begin{array}{r}800 \\
900 \\
1000 \\
1100\end{array}$ & $\begin{array}{r}1.0 \\
0.3 \\
-0.3 \\
-0.9\end{array}$ & $\begin{array}{l}7 \cdot 7 \\
7 \cdot 1 \\
6 \cdot 6 \\
5 \cdot 6\end{array}$ & $\begin{array}{l}9 \cdot 9 \\
9 \cdot 7 \\
9 \cdot 3 \\
9 \cdot 5\end{array}$ & $\begin{aligned} & 0.6 \\
- & 0.2 \\
- & 0.6 \\
- & 1.5\end{aligned}$ \\
\hline $\begin{array}{l}1200 \\
1300 \\
1400 \\
1500\end{array}$ & $\begin{array}{l}-1.0 \\
=1.2 \\
=1.2 \\
-1.0\end{array}$ & $\begin{array}{l}4 \cdot 8 \\
3.9 \\
2 \cdot 9 \\
2 \cdot 0\end{array}$ & $\begin{array}{l}9 \cdot 9 \\
9 \cdot 7 \\
8.9 \\
7 \cdot 6\end{array}$ & $\begin{array}{l}-2.4 \\
=2.9 \\
-2.9 \\
-2.6\end{array}$ \\
\hline $\begin{array}{l}1750 \\
2000\end{array}$ & $\begin{array}{l}-0.3 \\
0\end{array}$ & $\begin{array}{l}0 \cdot 3 \\
0\end{array}$ & $\begin{array}{r}3.8 \\
0\end{array}$ & $-\frac{1 \cdot 2}{0}$ \\
\hline
\end{tabular}

\section{Discussion}

The isolines of depth, acceleration potential, salinity and oxyty in the southern region under study run almost parallel to the latitudes indicating the flow at these latitudes should be essentially zonal. Based on a similar distribution of depth, salinity and oxyty, Taft (1963) concluded that there is no clear evidence of northward transport of low-salinity waters. Sharma (1976b) discussed in detail the transequatorial movement of water masses in the Indian Ocean and concluded that the transequatorial exchange of water masses is limited to very near the coasts.

Based on salinity minimum on the meridional profiles Tchernia et al (1958) inferred that the Antarctic Intermediate Water enters the North Indian Ocean crossing the equator and the low-salinity water in the Northwest Indian Ocean is attributed to the Antarctic Intermediate Water. But Taft (1963) pointed out that the salinity minimum in the region north of equator and the Antarctic Intermediate Water are not in a line of flow because they are at different steric levels, and concluded that the Antarctic Intermediate Water cannot be the source of the salinity minimum. Warren et al (1966) remarked that this condition cannot preclude a southern origin for the fresh water at depths less than those of the core of the Antarctic Intermediate Water and suggested that the shallow, northward moving Subtropical Subsurface Water lies above the high-salinity core of the North Indian Ocean Water and penetrates north of equator. As proposed by Warren et al (1966), if the low salinity Subtropical Subsurface Water were to penetrate north of equator, a salinity minimum in the vertical distribution of salinity should have been present all along the equator at levels where 
this water crosses the equator. A cursory glance of station curves along the equator reveals the absence of salinity minimum, and on the other hand vertical spreading of homogeneous water in the depth range of 100 to $1,000 \mathrm{~m}$ is conspicuous (Sharma 1972, 1976a). Furthermore, a close examination of meridional sections indicates the absence of any transequatorial flow except very near the coasts (Wyrtki 1971; Sharma 1976a) and this inference has been further confirmed by Sharma (1976b). As mentioned earlier, the orientation of isolines in the southern region shows zonal flow and hence, the possibility of any meridional flow in the southern Indian Ocean can be ruled out. As such, the South Indian Ocean cannot be the source of low-salinity water in the northwestern Indian Ocean. On the other hand, the distribution of salinity on the surface of $160 \mathrm{cl} / \mathrm{t}$ and $120 \mathrm{cl} / \mathrm{t}$ (figures $6 \mathrm{a}, 7 \mathrm{a}$ ) clearly demonstrates the low-salinity tongue emanating from the Eastern Archipelago. The characteristics of the water in the tongue are similar to those of the Equatorial Pacific Ocean Water (Tsuchiya 1968). The salinity distribution on other steric levels above $100 \mathrm{cl} / \mathrm{t}$ is in conformity with this feature (Rochford 1958; Taft 1963; Wyrtki 1971; Sharma 1972). Hence, the water appears to come southward from the Pacific Equatorial Currents by way of Banda and Timor seas, and penetrates the more saline water of the Indian Ocean as far west as $53 \mathrm{E}^{\circ}$ (figure $6 \mathrm{a}$ ). West of $53^{\circ} \mathrm{E}$, spreading of this water is obvious from the distribution of properties on 160 and $120 \mathrm{cl} / \mathrm{t}$ surfaces.

Taft (1963) attributed the low-salinity water in the northwestern Indian Ocean to the Pacific Ocean origin. Warren et al (1966) questioned this inference on the ground that the oxyty of the water coming from the Banda Sea is $2.3 \mathrm{ml} / 1$ and not over 2.5 $\mathrm{m} 1 / 1$ while that of the low-salinity water in the northwestern Indian Ocean is more than $3.0 \mathrm{ml} / 1$. Sharma (1972) contradicted this argument based on the fact that the difference in oxyty of the waters in the Somali Basin and the Eastern Archipelago is much less (less than $0.5 \mathrm{ml} / 1$ ) and it is probable that the oxyty of the water is increased through mixing with the high-oxyty water from the south during its flow to the west.

In a recent paper Premchand and Sastry (1976) while discussing the origin of the low-salinity water in the western Indian Ocean agreed with the absence of a direct line of flow of the South Indian Ocean Water (Antarctic Intermediate Water or the Subtropical Subsurface Water). However, they disagree with the point of view that this water is from the Pacific Ocean. They also disagree with the argument of Sharma (1972) that the higher oxyty in the Somali Basin over the Pacific Ocean Water is due to mixing with the higher-oxyty water of the south during its flow. They remarked 'If oxyties were to increase from $2.3 \mathrm{ml} / 1$ in the eastern Indian Ocean to $3.3 \mathrm{ml} / 1$ in the Somali Basin by mixing of high-oxyty waters (say, of oxyty $4 \mathrm{ml} / \mathrm{l}$ ) with the waters of Pacific origin in equal volumes, the mixture still possesses lower oxyties than those observed in the Somali Basin.' The oxyty values over $3.3 \mathrm{ml} / 1$ which these authors reported are the maxima of oxyty not in the salinity minimum but 100 to $150 \mathrm{~m}$ above salinity minimum in the Somali Basin which is evident from Warren et al (1966 p. 840) who stated Near the continental slope on Profiles A and B (figures 3 and 4) the oxygen maximum exceeds $3.0 \mathrm{ml} / 1$ but lies some $150 \mathrm{~m}$ above the salinity minimum. Elsewhere, except at Sta. 45 (figure 5) and at Sta. 67 (figure 8) are comparably high values seen, and except at $S t a .67$, the vertical separation between the oxygen maximum and the salinity minimum is smaller than on Profiles $A$ and $B$, less than $100 \mathrm{~m}$. The high oxygen layer is least apparent on Profile F(figure 8); at Stas. 64 and 65, where there is a well-developed salinity minimum, there is only a faintest indication of an oxygen maximum in the serial observations (none in the isopleths)'. Furthermore, 
the value of oxyty in the Equatorial Pacific Ocean Water which penetrates into the Indian Ocean south of $10^{\circ} \mathrm{S}$ through the Banda and Timor seas on and above $100 \mathrm{cl} / \mathrm{t}$. surface is not less than 2.5 ml/1 (Taft 1963; Reid 1965; Tsuchiya 1968). Hence, the increase in oxyty of the Pacific Ocean Water is not more than $0.5 \mathrm{ml} / \mathrm{l}$ through mixing with the higher-oxyty water of the south. Further, the process of mixing is accelerated by the shear developed due to the presence of the South Equatorial Countercurrent at about $13^{\circ} \mathrm{S}$ which flows in the opposite direction to that of the South Equatorial Current along which the Pacific Ocean Water is carried (Sharma 1976a). On the contrary, as suggested by Premchand and Sastry (1976) if the Antarctic Intermediate Water which shows the oxyty to be $5.5 \mathrm{ml} / 1$ at $100 \mathrm{cl} / \mathrm{t}$ at the two Vityaz stations 5182 and 5184 just above the salinity minimum were to be drawn into the Somali Basin along the West Australian Current, and if we assume the mixing takes place with the water having the lowest value of $2.5 \mathrm{ml} / 1$ oxyty and equal proportion of these two waters, the resulting mixture should not have the oxyty less than $4.0 \mathrm{ml} / \mathrm{l}$. Another point of view expressed by these authors to show that the low-salinity water is not from the Pacific Ocean is the absence of salinity minima at Diamantina station $(2 / 62)$ 86 at $7^{\circ} 41^{\prime} \mathrm{S} ; 105^{\circ} 01^{\prime} \mathrm{E}$ and Vityaz station (35) 5184 at $21^{\circ} 45 \cdot 2^{\prime} \mathrm{S} ; 108^{\circ} 26 \cdot 3^{\prime} \mathrm{E}$. Primarily, it should be noted that the Pacific Ocean Water enters the Indian Ocean only south of $10^{\circ} \mathrm{S}$ through Banda and Timor seas. Hence the water characteristics at $\operatorname{Dm}(2 / 62) 86$ cannot be representative of the Pacific Ocean Water. Secondly, the salinity minimum can be conspicuous if the low-salinity water is sandwiched between two high-salinity waters. The Pacific Ocean Water in the eastern Indian Ocean is characterized only as a vertical extent of low-salinity water above $100 \mathrm{cl} / \mathrm{t}$. As this water mass moves westward, in the Somali Basin it is sandwiched between the two salinity maxima arising out of the Red Sea and Persian Gulf waters which are present on the isanosteres below $100 \mathrm{cl} / \mathrm{t}$ and above $120 \mathrm{cl} / \mathrm{t}$ respectively. As suggested by Premchand and Sastry (1976) if the Antarctic Intermediate Water is to be carried along with the West Australian Current, the isohalines as well as the isolines of acceleration potential should have shown a meridional orientation instead of zonal orientation which, obviously, indicates the absence of the Antarctic Intermediate Water above $100 \mathrm{cl} / \mathrm{t}$ surface north of the South Equatorial Countercurrent.

The salinity structure on the meridional sections (Wyrtki 1971) indicates a break up between $15^{\circ} \mathrm{S}$ and $10^{\circ} \mathrm{S}$, with low-salinity water separating the high-salinity waters from the north and south. The characteristics of this water in the break up are similar to those of the Equatorial Pacific Ocean Water (Tsuchiya 1968).

On 80 and $60 \mathrm{cl} / \mathrm{t}$ surfaces incursion of the Pacific Ocean Water is not noticed and on the converse, the North Indian Ocean Water penetrates towards the Eastern Archipelago as a high-salinity tongue (figures 8a, 9a).

A first glance of the distribution of acceleration potential as well as the depth and salinity maps gives an impression that the distribution in these properties is markedly changed in the Archipelago region because of a few stray values at the Umitaka Maru stations. But a closer examination of the $T-S$ curves shows that the varation is consistent with the observations at neighbouring stations covered by other vessels.

\section{Conclusion}

Low-salinity water from the Pacific Ocean intrudes into the western Indian Ocean 
along the South Equatorial Current, in the layers above $100 \mathrm{cl} / \mathrm{t}$. Below $100 \mathrm{cl} / \mathrm{t}$ relatively higher-salinity water of the North Indian Ocean appears to penetrate into the Eastern Archipelago and ultimately into the Pacific Ocean. However, further studies are to be carried out with more data in the Eastern Archipelago region to confirm the incursion of the North Indian Ocean Water into the Pacific Ocean.

The low-salinity water in the northwestern Indian Ocean at intermediate depths has its origin in the Pacific Ocean. Neither the Antarctic Intermediate Water nor the Subtropical Subsurface Water enter the North Indian Ocean except very near the coasts.

The South Equatorial Countercurrent and the Tropical Countercurrent are found at $12^{\circ} \mathrm{S}-15^{\circ} \mathrm{S}$ and $20^{\circ} \mathrm{S}-24^{\circ} \mathrm{S}$ respectively. The latitudinal position of these currents vary with longitudes.

\section{Acknowledgements}

The authors wish to thank Joseph L. Reid, Scripps Institution of Oceanography, La Jolla, California, for going through the manuscruipt and making valuable suggestions for improvement.

\section{References}

Helland-Hansen B 1930 Rep. Sars. N. Atl. Deep-Sea Exped. 1317

Montgomery R B 1937 Bull. Amer. Met. Soc. 8276

Montgomery R B and Spilhaus A F 1941 J. Aero. Sci. 18210

Montgomery R B and Stroup E D 1962 Johns Hopk. Oceanogr. Stud. 1 p. 68

Premchand K and Sastry J S 1976 Indian J. Mar. Sci. 5169

Reid J L 1959 Nature (London) 184209

Reid J L 1965 Johns. Hopk. Oceanogr. Stud. 2 p. 85

Rochford D J 1958 J. Mar. Res. 17483

Sharma G S 1972 J. Mar. Res. 30102

Sharma G S 1976a J. Oceanogr. Soc. Jpn. 32284

Sharma G S 1976b J. Mar Res. 43143

Sverdrup H U, Johnson M W and Fleming R H 1942 The oceans: their physics, chemistry and general biology (New York: Prentice-Hall) p. 1087

Taft B A 1963 J. Mar. Res. 21129

Tchernia Paul, Lacombe H and Guibout P 1958 C.O.E.C. Bull. d' Inform. 10115

Tsuchiya M 1968 Johns Hopk. Oceanogr. Stud. 4 p. 50

Uda M and Hasunuma K 1969 J. Oceanogr. Soc.Jpn. 25201

Uda M and Nakamura Y 1973 Spl publ. Mar. Biol. Ass. India 276

Warren B, Stommel H and Swallow J C 1966 Deep-Sea Res. 13825

Wyritki Klauss 1957 Proc. 9th Pacif. Sci. Congr. 1661

Wyrtki Klauss 1971 Oceanographic Atlas of the International Indian Ocean Expedition National Science Foundation, Washington p. 531.

Yoshida K and Kidokoro T 1967a J. Oceanogr. Soc. Jpn. 2388

Yoshida K and Kidokoro T 1967b J. Oceanogr. Soc. Jpn. 23231 